\title{
Response of Coastal Shewanella and Duganella Bacteria to Planktonic and Terrestrial Food Substrates
}

\section{OPEN ACCESS}

Edited by:

Gordon T. Taylor,

Stony Brook University, United States

Reviewed by:

David A. Walsh,

Concordia University, Canada

Milla Rautio,

Université du Québec à Chicoutimi,

Canada

*Correspondence:

Agneta Andersson

agneta.andersson@umu.se

Specialty section:

This article was submitted to

Aquatic Microbiology,

a section of the journal

Frontiers in Microbiology

Received: 17 June 2021 Accepted: 16 December 2021

Published: 16 February 2022

Citation:

Zhao L, Brugel S, Ramasamy KP and Andersson A (2022) Response of Coastal Shewanella and Duganella Bacteria to Planktonic and Terrestrial

Food Substrates.

Front. Microbiol. 12:726844. doi: 10.3389/fmicb.2021.726844

\section{Li Zhao ${ }^{1,2}$, Sonia Brugel 1,2, Kesava Priyan Ramasamy ${ }^{1,2}$ and Agneta Andersson 1,2* \\ 'Department of Ecology and Environmental Science, Umeå University, Umeå, Sweden, ${ }^{2}$ Umeå Marine Sciences Centre, Umeå University, Hörnefors, Sweden}

Global warming scenarios indicate that in subarctic regions, the precipitation will increase in the future. Coastal bacteria will thus receive increasing organic carbon sources from land runoff. How such changes will affect the function and taxonomic composition of coastal bacteria is poorly known. We performed a 10-day experiment with two isolated bacteria: Shewanella baltica from a seaside location and Duganella $\mathrm{sp}$. from a river mouth, and provided them with a plankton and a river extract as food substrate. The bacterial growth and carbon consumption were monitored over the experimental period. Shewanella and Duganella consumed $40 \%$ and $30 \%$ of the plankton extract, respectively, while the consumption of the river extract was low for both bacteria, $\sim 1 \%$. Shewanella showed the highest bacterial growth efficiency (BGE) $(12 \%)$ when grown on plankton extract, while when grown on river extract, the BGE was only $1 \%$. Duganella showed low BGE when grown on plankton extract $(<1 \%)$ and slightly higher BGE when grown on river extract (2\%). The cell growth yield of Duganella was higher than that of Shewanella when grown on river extract. These results indicate that Duganella is more adapted to terrestrial organic substrates with low nutritional availability, while Shewanella is adapted to eutrophied conditions. The different growth performance of the bacteria could be traced to genomic variations. A closely related genome of Shewanella was shown to harbor genes for the sequestration of autochthonously produced carbon substrates, while Duganella contained genes for the degradation of relatively refractive terrestrial organic matter. The results may reflect the influence of environmental drivers on bacterial community composition in natural aquatic environments. Elevated inflows of terrestrial organic matter to coastal areas in subarctic regions would lead to increased occurrence of bacteria adapted to the degradation of complex terrestrial compounds with a low bioavailability.

Keywords: coastal bacteria, Duganella sp., Shewanella baltica, river organic carbon, plankton organic carbon, bioavailability, bacterial growth efficiency, response

\section{INTRODUCTION}

Heterotrophic bacteria are important players in the biogeochemical cycles of the major elements on Earth. They have a dual role in the ecosystems as being the major mineralizers of organic matter into inorganic elemental forms and the contributors to the food web production (del Giorgio and Cole, 1998). Understanding how bacterial growth is regulated is of crucial importance, for example, to be able to construct models of the cycling of carbon, nitrogen, and phosphorus. In aquatic 
systems, the bacterial carbon biomass production, in general, follows the net primary production (e.g., del Giorgio and Cole, 1998), suggesting that organic matter produced by phytoplankton is the major substrate for heterotrophic bacteria. However, this view has been questioned, since bacterial carbon demand often exceeds phytoplankton primary production especially in low productive systems (Fouilland and Mostajir, 2010). In northerly estuaries profoundly influenced by river inflow from boreal regions, the bacterial production can even exceed the primary production (Figueroa et al., 2016; Andersson et al., 2018b). Thus, both autochthonous and allochthonous dissolved organic matter can constitute food sources for aquatic bacteria.

Dissolved organic carbon (DOC) is a major component of the dissolved organic matter in aquatic systems. The easily available fraction of the DOC is, however, quite low, 1-20\% (Zweifel et al., 1993; Søndergaard and Middelboe, 1995; Pedler et al., 2014; Figueroa et al., 2016), due to the refractive character of old DOC (Bianchi, 2011). In contrast, the bioavailability of newly produced autochthonous organic carbon is generally considered to be high, and bacteria are quickly consuming this fraction. However, in some cases, the reactivity of autochthonous organic carbon sources has been shown to be relatively low (Catalán et al., 2013). Furthermore, it is likely that the availability of nitrogen and phosphorus also affects the assimilation of DOC by bacteria due to their stoichiometric demands.

A key variable for understanding ecosystem effects of bacterial activity is the bacterial growth efficiency (BGE), which indicates how much of the consumed organic carbon is channeled into new biomass and the proportion that is being remineralized. Earlier studies have shown that the BGE correlates positively with the bacterial growth rates and the net primary productivity in the ecosystem (del Giorgio and Cole, 1998; Alonso-Sáez et al., 2008). When the bacterial production decreases, a larger proportion of the consumed carbon is allocated for maintenance energy and the growth efficiency decreases (del Giorgio and Cole, 1998; Eiler et al., 2003; Vikström and Wikner, 2019). Thus, a larger fraction of the consumed carbon would be respired, and a smaller fraction used for building new biomass. BGE can, however, be affected by various factors, such as nutrients, temperature, substrate quality, and the adaptation of the bacterial community to the environment (Vázquez-Domínguez et al., 2007; Lønborg et al., 2011; González-Benítez et al., 2019; Baña et al., 2020; Yeh et al., 2020).

Field studies have shown that specific bacterial taxa dominate in different aquatic habitats (e.g., Teira et al., 2009; Herlemann et al., 2011; Broman et al., 2019). Betaproteobacteria and Actinobacteria are common in low salinity waters, while Gammaproteobacteria and Alphaproteobacteria are more abundant in high saline waters (e.g., Herlemann et al., 2011; Broman et al., 2019). This distribution may be explained not only by salinity variation but also by co-varying factors, like terrestrial organic carbon. Earlier studies have shown a link between high concentrations of humic substances in the environment and dominance of Betaproteobacteria (Teira et al., 2009), which might be explained by the presence of genes for the degradation of aromatic compounds in this bacterial group (Pérez-Pantoja et al., 2012). It is, however, so far unknown whether the Betaproteobacteria are utilizing terrestrial DOC more efficiently than other types of bacteria, and if that is coupled to specific genomic properties. Likewise, we lack information about the genetic and functional adaptation of bacteria that are known to thrive in eutrophied conditions, like Gammaproteobacteria (Andersson et al., 2018a). One way to approach that knowledge gap is to use single bacterial species isolated from different habitats, test these for growth on habitat-related substrates, and link to their genomic properties. If the bacteria are carefully isolated using relevant substrates, they may serve as models to study bacterial ecophysiology and biogeochemistry (Hagström et al., 2017).

Climate change is projected to cause $\sim 30 \%$ increased precipitation in the European subarctic region within the next 100 years, which will cause increased inflows of brown-colored humic-rich river water to the northern Baltic Sea (Andersson et al., 2018b). The coastal bacteria may thus experience increased availability of allochthonous terrestrial organic matter as food source, while the autochthonous substrate decreases as primary production diminishes due to light shading (Andersson et al., $2015,2018 b$ ). Here we aimed to elucidate how such a change in food source would affect different coastal bacteria. An experiment was performed where two bacteria isolated from the northern Baltic Sea, Duganella sp. (Betaproteobacteria) and Shewanella baltica (Gammaproteobacteria), were provided two different types of substrates. One substrate consisted of ultrafiltered river water; the other was a marine plankton lysate. We hypothesized that the plankton extract would be more bioavailable than the river extract, and that the bacterial abundance yield should follow the bioavailability of the added food substrate. The BGE was expected to increase with the amount of added food substrate, but we assumed that quality should be even more important, i.e., that the high-quality plankton extract should result in high BGE and that low qualitative river extract should result in low BGE. Furthermore, we expected Shewanella, isolated from a seaside coastal site, to be more adapted to the utilization of the plankton extract and Duganella, isolated from a river mouth, to be more adapted to the utilization of the river extract. Finally, we anticipated that differences could be linked to genomic differences between the bacteria. This would imply that studies of isolated species can be ecologically relevant and assist in the understanding of ecosystem processes.

\section{MATERIALS AND METHODS}

\section{Media for Isolation of Bacteria}

Bacteria were isolated on agar plates using two different media: a plankton extract and a river extract-based medium. Sterile aged seawater was used as the base of both media. Seawater was collected at $1.5-\mathrm{m}$ depth at a coastal site in the northern Baltic Sea. The water was $0.22-\mu \mathrm{m}$-filtered and autoclaved, stored in the dark at $4^{\circ} \mathrm{C}$ for four weeks before use. Agar plates with sterile-filtered plankton and river extract were mixed with sterile aged seawater and $1.5 \%$ agar. The organic carbon concentration in both types of agar plates was $350 \mu \mathrm{molC}^{-1}{ }^{-1}$, 
which is similar to the DOC concentration in the Baltic Sea (e.g., Andersson et al., 2018b).

\section{Plankton and River Extracts}

To obtain the plankton extract, about 750,000 l of coastal water was pumped from 5-m depth during the spring period, and the plankton was collected on a 90- $\mu \mathrm{m}$ nylon mesh. The collected plankton was kept cold and dark until extraction. The plankton was extracted by adding glass beads to Eppendorf tubes and disintegrating the organisms using a tissue lyser (Tissue Lyser II, Qiagen). The extract was centrifuged for $10 \mathrm{~min}$ to remove cell debris, and the supernatant was collected, $0.2-\mu \mathrm{m}$-filtered, and stored at $-20^{\circ} \mathrm{C}$ until analysis.

To analyze the plankton composition of the sample used for disintegration, a subsample was preserved with $2 \%$ Lugol's solution and counted using the inverted microscope method (Utermöhl, 1958). Nanoplankton, microplankton, and mesozooplankton were counted at 400x, 100x, and 40x, respectively. Nano- and microplankton biomass was calculated from the geometric shape of the cells following the work of Olenina et al. (2006), and the cell carbon content was calculated according to Menden-Deuer and Lessard (2000). Zooplankton carbon biomass was calculated according to Hernroth (1985). The plankton extract was composed of high molecular weight biopolymers (data not shown).

To obtain a river extract, about 151 of river water was collected $5 \mathrm{~km}$ upstream the Öre River mouth during spring. The river water was processed by tangential flow filtration using a Centramate cassette holder (PALL) fitted with a suspendedscreen ultrafiltration cassette with an Omega membrane of $300 \mathrm{kDa}$ (PALL) over 1 day to remove larger particles. The remaining filtrate (14 l) was then ultrafiltered using a cassette of $1 \mathrm{kDa}$ (a suspended-screen ultrafiltration cassette with an Omega membrane, PALL) to a volume of 2.51 . The river extract consequently consisted of high molecular weight organic compounds $(>1 \mathrm{kDa})$.

Both the plankton and river extracts were thus composed of high molecular weight organic compounds, representing dissolved organic matter (DOM) in the size range 1-200-300 nm (Benner and Amon, 2015).

\section{Chemical Analyses}

The carbon, nitrogen, and phosphorus concentrations in the plankton and river extracts were analyzed by measuring dissolved organic carbon (DOC), total N, and total P. DOC analyses were carried out on 0.2- $\mu \mathrm{m}$-filtered (Supor Membrane Syringe Filter, non-pyrogenic, Acrodisc $\left.{ }^{\circledR}\right)$ and acidified $(8 \mathrm{mM} \mathrm{HCl}$ final concentration) extract samples on a Shimadzu TOC5000 analyzer. Total phosphorus (TP) and total nitrogen (TN) were measured in unfiltered samples using a Seal QuAAtro39 autoanalyzer after an oxidation step using peroxodisulfate, according to standard analytical methods (Grasshoff et al., 1983).

\section{Isolation of Bacteria}

Heterotrophic bacteria were isolated at two sampling sites in the northern Baltic Sea in July 2017. One site was located in the Öre River mouth $\left(63^{\circ} 30.8094,19^{\circ} 43.80\right)$ and the other at the coastal seaside $\left(63^{\circ} 30.3713,19^{\circ} 49.14\right)$ (Supplementary Figure 1). Water was collected at $0.5-\mathrm{m}$ depth using a Ruttner sampler. At the Öre River mouth, the salinity was $0.9 \mathrm{psu}$, the temperature was $14^{\circ} \mathrm{C}$, and the DOC concentration was $\sim 667 \mu$ molC. $1^{-1}$. At the coastal site, the salinity was $4.4 \mathrm{psu}$, the temperature was $12.1^{\circ} \mathrm{C}$, and the DOC concentration was $\sim 333 \mu$ molC. $1^{-1}$.

Triplicate 100- $\mu$ l samples from the Öre River mouth and the coastal site were spread on river agar plates and plankton agar plates. The plates were incubated at $20^{\circ} \mathrm{C}$ in dark conditions for $\sim 10$ days. Five colonies from each plate were re-streaked three times on the same type of agar plates to secure that single cell colonies were obtained. However, no bacteria was successfully isolated when samples from the coastal seaside were spread on river agar plates. Strains were then conserved in frozen stocks with $10 \%$ glycerol at $-80^{\circ} \mathrm{C}$ until further processing. For the subsequent test, the strains were grown in liquid broth (peptone 10 g. $1^{-1}$, yeast extract 5 g. $1^{-1}$, aged seawater) at $20^{\circ} \mathrm{C}$ with shaking (50 rpm).

\section{DNA Extraction and 16S rRNA Gene Sequencing}

Ten bacteria isolated from the river mouth and the seaside location were randomly selected and analyzed. The strains were identified by $16 \mathrm{~S}$ rRNA gene sequencing. DNA was extracted with a Powersoil DNA isolation kit (Qiagen) according to the manufacturer's recommendations. The $16 \mathrm{~S}$ rRNA gene was amplified with the general bacterial primers 27f (5'AGAGTTTGATCCTGGCTCAG-3 $\left.3^{\prime}\right)$ and 1492r (5'GGTTACCTTGTTACGACTT-3') (Lane, 1991). The PCR mixture contained $0.2 \mu \mathrm{M}$ of each primer and $40 \mathrm{ng}$ of DNA in a total volume of $100 \mu \mathrm{l}$ (HotStar Taq Master Mix Kit, Qiagen). The PCR cycling regime was (1) one cycle of 15-min denaturation and Taq activation at $95^{\circ} \mathrm{C}$; (2) 30 cycles of $60 \mathrm{~s}$ at $95^{\circ} \mathrm{C}, 45 \mathrm{~s}$ at $50^{\circ} \mathrm{C}$, and $90 \mathrm{~s}$ at $72^{\circ} \mathrm{C}$; and (3) one final extension cycle of $10 \mathrm{~min}$ at $72^{\circ} \mathrm{C}$. PCR products were verified by standard agarose gel electrophoresis, and about $300 \mathrm{ng}$ of each amplified DNA was sent to Macrogen (Netherland) for paired-end sequencing. Nearly full-length $16 \mathrm{~S}$ rDNA sequences were obtained. The sequences were deposited in GenBank under accession numbers MW032666 to MW032685.

The BLASTn program from the National Center for Biotechnology Information (NCBI) web pages ${ }^{1}$ was used to identify the isolated 20 bacterial strains based on 16S rDNA sequences. We searched for taxa with high sequence similarity using the EMBL/GenBank/DDBJ databases. Among the isolates from the seaside location, $60 \%$ were identified as Shewanella baltica, and among the isolates from the river mouth, 80\% were identified as Duganella sp. (Supplementary Table 1). One Shewanella baltica (MW032670) and one Duganella sp. (MW032681) with the highest similarity were selected for the microcosm experiment.

\section{Bioinformatic Analysis of Bacterial Carbon Metabolism}

We performed in silico analysis to identify the protein homologs involved in $\mathrm{C}, \mathrm{N}$, and $\mathrm{P}$ metabolism by comparing with

\footnotetext{
${ }^{1}$ http://www.ncbi.nlm.nih.gov/BLAST/
} 
the closest publicly available genome in NCBI. The isolated bacterial strains showed closest similarities to Shewanella baltica OS117 (99.85\%) and Duganella sp. AF9R3 (99.71\%). The NCBI accession numbers are NC_017579.1 and NZ_CP051684.1. The completely annotated protein sequences are available following the below links.

https://www.ncbi.nlm.nih.gov/genome/browse/\#!/proteins/ 434/166825\%7CShewanella\%20baltica\%20OS117/

https://www.ncbi.nlm.nih.gov/genome/browse/\#!/proteins/ 40889/888716\%7CDuganella\%20sp.\%20AF9R3/

The NCBI accession number for each protein coding genes is included in Supplementary Table 2. Clusters of orthologous groups of proteins (COGs) functional categorization was performed using available tools on the JGI IMG database (Chen et al., 2021). The genomes of Shewanella baltica OS117 and Duganella sp. AF9R3 are available in the IMG database with the following genome IDs: 651053066 and 2884672076 , respectively. The abundance profile tool was used to identify the presence/absence of specific genes for protein families in the genome.

\section{Microcosm Experiment Experimental Design}

One bacterium isolated from the coastal seaside location, Shewanella baltica, and one bacterium from the river mouth, Duganella sp., were used in a 10-day microcosm experiment, where their growth responses and functions were studied in relation to different food substrates.

Each bacterium was provided with four different food substrates: (1) plankton extract (final DOC concentration $\sim 667 \mu \mathrm{molC} . \mathrm{l}^{-1}$ ), (2) river extract (final DOC concentration $\left.\sim 583 \mu \mathrm{molC} . \mathrm{l}^{-1}\right)$, (3) river extract + phosphorus $\left(\sim 583 \mu \mathrm{molC}^{-1}\right)^{-1}$ ), and (4) sterile seawater (Control, final DOC concentration $\sim 333 \mu$ molC. $\left.1^{-1}\right)$. The river extract addition followed a climate change scenario where the precipitation, and thus the river inflow, is estimated to increase $30-50 \%$ over the next coming 100 years (e.g., Eriksson-Hägg et al., 2014; Andersson et al., 2015). Furthermore, we added approximately a similar amount of carbon from the plankton extract as from the river extract in order to be able to test the effects of qualitative differences. To further test the effects of quality on the bacterial growth, we added phosphorus to one treatment with the river extract, since the river extract contained extremely little phosphorus. Sterile (autoclaved) seawater $(0.2 \mu \mathrm{m}$ filtered) served as the base medium in all treatments. The microcosms with solely sterile seawater served as a control. Each treatment had three replicates. The salinity in the experiment was 3.5-4 psu.

The microcosm experiment was performed in 2-1 Erlenmeyer flasks with vented screw caps $(3$ replicates $\times 4$ treatments $\times 2$ bacteria $=24$ microcosms). The water volume was 11 , and the experiment was performed as a batch culture incubated at $15^{\circ} \mathrm{C}$ in the dark.

The bacteria were pre-grown in a liquid broth medium (aged seawater, tryptone $10 \mathrm{~g} \cdot \mathrm{l}^{-1}$, yeast extract $5 \mathrm{~g} \cdot \mathrm{l}^{-1}$ ), and the cell abundance was measured by flow cytometry. After washing the bacteria in sterile seawater, $\sim 10^{5}$ bacteria $\mathrm{ml}^{-1}$ were added to each microcosm. Samples were then taken from the microcosms on days $0,3,6$, and 9. Bacterial abundance was monitored in order to measure bacterial growth yield. DOC was monitored in order to measure the bacterial consumption of DOC and the bioavailability of the different types of DOC. Bacterial growth yield and DOC consumption were used to estimate the bacterial growth efficiency. Nitrogen and phosphorus were measured to monitor bacteria-induced transformations.

\section{Bacterial Abundance}

Bacterial abundance was measured using flow cytometry. At each sampling day, $2 \mathrm{ml}$ of sample was preserved with glutaraldehyde $(0.1 \%$ final concentration $)$ and stored at $-80^{\circ} \mathrm{C}$ for subsequent analysis. Samples were stained with SYBR Green I (Invitrogen) to a final concentration of 1:10,000 (Marie et al., 2005). The samples were run at a flow rate of $60 \mu \mathrm{l} \cdot \mathrm{min}^{-1}$ for $1 \mathrm{~min}$ using a BD FACSVerse ${ }^{\mathrm{TM}}$ flow cytometer (BD Biosciences) equipped with a 488-nm laser (20-mW output), with $1-\mu \mathrm{m}$ microspheres (Fluoresbrite plain YG, Polysciences) as the internal standard. The average light side scatter was measured to follow the average cell volume of the bacterial population in each sample.

\section{Bacterial Biomass}

The bacteria were filtered onto $0.2-\mu \mathrm{m}$ black polycarbonate filters, stained with SYBR Green I (Invitrogen) at a final concentration of 1: 10,000, and their size was measured under blue excitation with epifluorescence microscopy (magnification x 1000, Nikon Eclipse TiU). After calculating the cell volume, the biomass was calculated from Norland's relationship: carbon biomass $\left(\mathrm{mgC}\right.$.cell $\left.{ }^{-1}\right)=0.12 \times 10^{-9} \times \mathrm{CV}^{0.7}$, where $\mathrm{CV}$ is the cell volume in $\mu \mathrm{m}^{3}$ (Norland, 1993).

\section{Dissolved Organic Carbon, Total, and Inorganic Nitrogen and Phosphorus Tot $\mathrm{N}$ and Tot $\mathrm{P}$}

Dissolved organic carbon (DOC) was analyzed as described above. Inorganic phosphorus (phosphate, $\mathrm{PO}_{4}{ }^{3-}$ ) and dissolved inorganic nitrogen (DIN: nitrate + nitrite and ammonium) were measured using a Seal QuAAtro39 autoanalyzer according to standard analytical methods (Grasshoff et al., 1983). Total dissolved nitrogen (TDN) and phosphorus (TDP) were measured on $0.2-\mu \mathrm{m}$-filtered (Supor Membrane Syringe Filter, nonpyrogenic, Acrodisc ${ }^{\circledR}$ ) samples as inorganic nutrients after an oxidation step using peroxodisulfate using a Seal QuAAtro39 autoanalyzer (Grasshoff et al., 1983).

\section{Dissolved Organic Carbon Availability, Bacterial Cell Yield, and Growth Efficiency}

The DOC bioavailability was calculated as the proportion of DOC that was consumed by bacteria at the end of the growth phase (day 6). Bacterial growth yield was calculated by subtracting the abundance/biomass at the end of the growth phase from the start abundance/biomass. The BGE was calculated by dividing the bacterial carbon biomass produced by the consumption of DOC for the corresponding period (del Giorgio and Cole, 1998).

\section{Statistical Analyses}

The comparisons of treatments were analyzed using KruskalWallis test followed by Mann-Whitney pair test, while the 
Epps-Singleton test with a small sample size correction was preferred for the comparison between bacterial taxa owing to the distribution of the data and the small sample size (Epps and Singleton, 1986). All statistical analyses were performed with the PAST 4.03 software (Hammer et al., 2001).

\section{RESULTS}

\section{Carbon Consumption and Bioavailability of the Plankton and River Extracts}

In most of the microcosms, the bacterial abundance increased from day 0 to day 6 , whereby a plateau was reached (Figure 1). Concurrently, the DOC concentration decreased from day 0 to day 6 (Figure 2), as did also TDN and TDP concentrations in some of the incubations (Supplementary Figures 2, 3). The major reactivity time was thus identified to be from day 0 to day 6 , and this period was used in further analysis of bacterial functions.
The DOC concentration at the start of the experiment was $\sim 316 \mu$ molC. $1^{-1}$ in the controls, $716 \mu \mathrm{molC}^{-1}$ in the plankton extract supplemented microcosms, and $616 \mu \mathrm{molC}^{-1}$ in the river extract supplemented microcosms (Figures 2, 3A,B). As described, our aim was to supply the two extract types in the same DOC concentration and according to a climate change scenario. Even though we did not supplement the extracts in the exact same concentrations, both were added within the range of the climate change scenario.

The plankton extract was mainly composed of lysed copepods ( $\sim 75 \%)$ and cladocerans ( 25\%) (Supplementary Table 3). Additionally, the lysate also contained smaller shares of phytoplankton (diatoms, cyanobacteria, cryptophyceans, and chlorophyceans) and rotifers. The C:N molar ratio was 1,216, 825 , and 825 in the plankton extract, the river extract, and the river extract $+\mathrm{P}$, respectively (Table 1 ). Both the plankton and river extracts were composed of high molecular weight dissolved organic compounds. The plankton extract consisted of biopolymers, and the river extract consisted of terrestrial
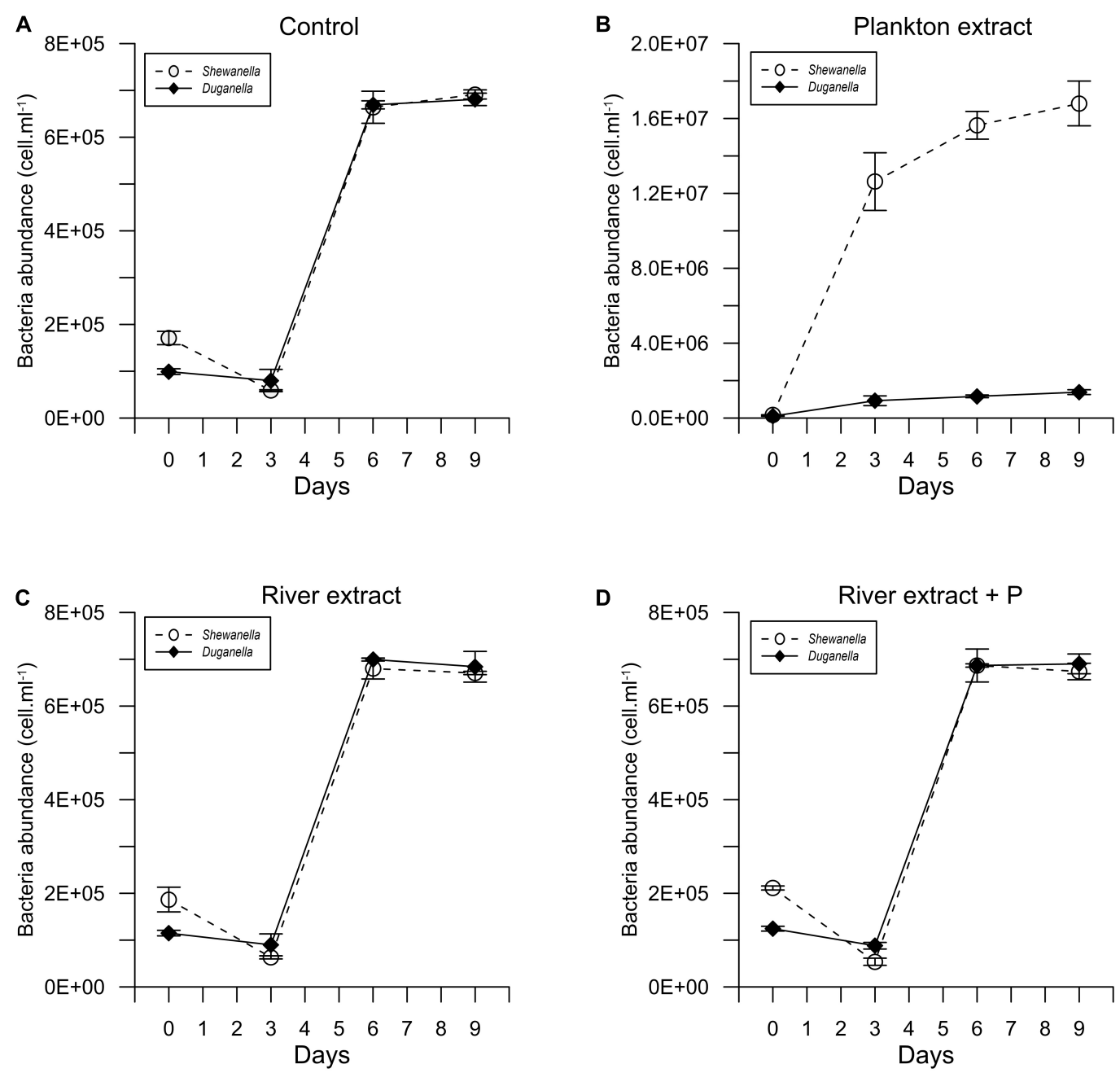

FIGURE 1 | Temporal variation of the abundance of Shewanella and Duganella in the (A) control, (B) plankton extract, (C) river extract, and (D) river extract + $\mathrm{P}$ supplemented microcosms. Data points show average values, and error bars denote standard deviation. 

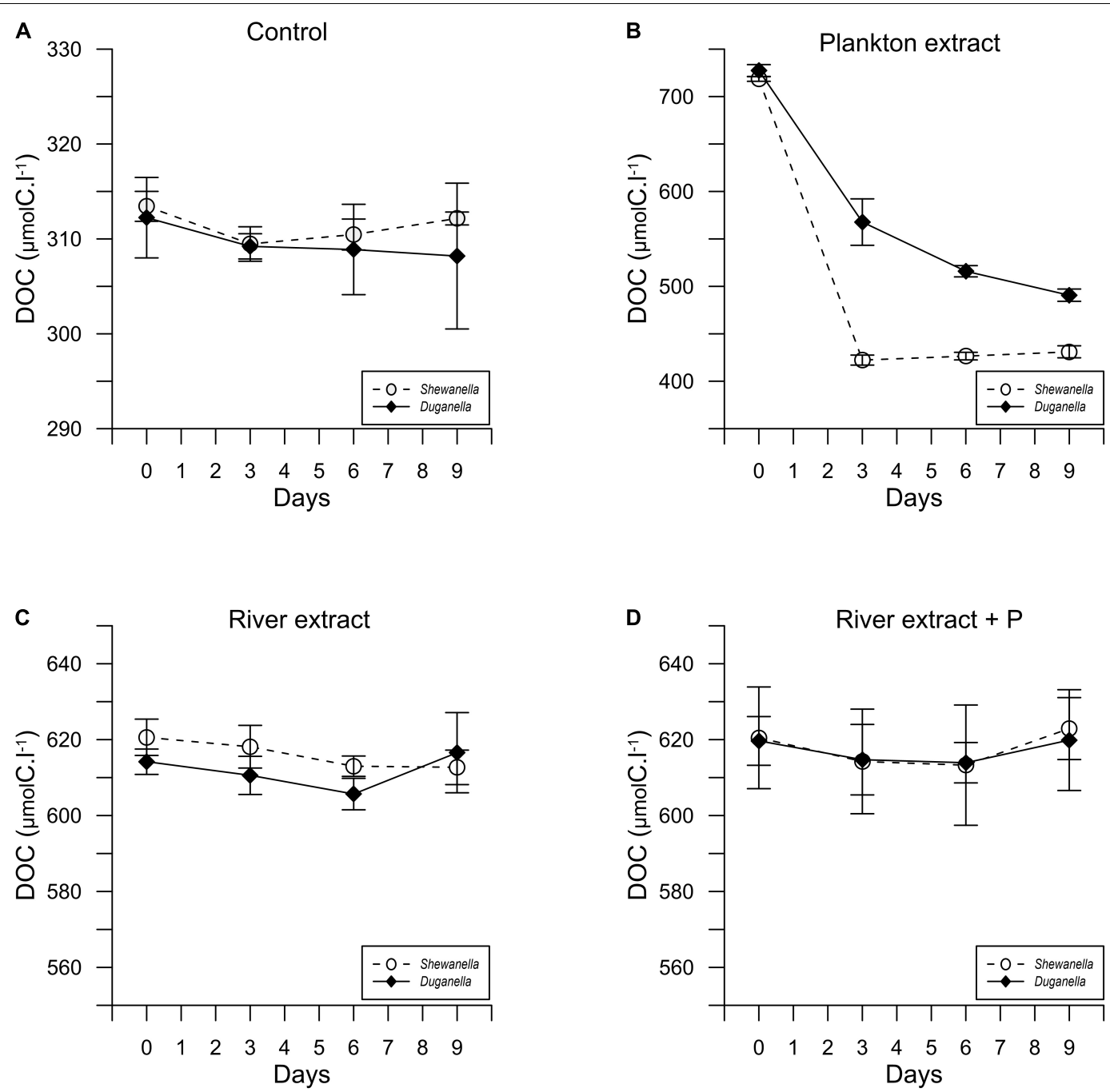

FIGURE 2 | Temporal variation of the DOC concentration in Shewanella and Duganella incubations: (A) control, (B) plankton extract, (C) river extract, and (D) river extract + P. Data points show average values, and error bars denote standard deviation.

compounds. The C:P molar ratio was 78 and 58,947 in the plankton and river extracts, respectively (Table 1). To compensate for the extremely low $\mathrm{P}$ content in the river extract, $\mathrm{PO}_{4}{ }^{3-}$ was added to one set of the river extract supplemented microcosms. The start CNP stoichiometry in the different treatments showed similar trends as the extracts, but the values were adjusted as the extracts were diluted in sterile seawater, which constituted the experimental base medium (Table 1).

The DOC availability, i.e., the DOC utilization, calculated from changes during the first 6 days of the experiment, ranged between 1 and $2 \%$ in the controls, the river extract, and the river extract $+\mathrm{P}$ supplemented microcosms, and the numbers were relatively similar for both the Shewanella and the Duganella bacterium (Figures 3C,D). The DOC bioavailability was the same in the control, based exclusively on seawater, than in the river extract treatments. Furthermore, the $\mathrm{P}$ addition to the river extract addition did not significantly increase the DOC availability. The bioavailability of the plankton extract treatment was significantly higher for Shewanella (40.6 $\pm 0.4 \%$ ) compared to Duganella $(29.1 \pm 1.3 \%)$ (Epps-Singleton test, $p<0.01)$ (Figures 3C,D). Shewanella was thus more adapted to utilize the plankton extract than Duganella.

The DOC utilization was significantly higher in the plankton extract addition than in the river extract addition (MannWhitney test, $p<0.01$; Figures $4 \mathrm{E}, \mathrm{F})$. The difference was large (30-fold) and could be explained not by the different amounts added to the microcosms but rather by quality differences.

\section{Variation in Nutrient Concentrations}

The TDN concentration remained relatively constant in the control and river extract additions, while TDN was consumed in the plankton extract addition (Supplementary Figure 2), where Shewanella showed a higher consumption than Duganella (Epps-Singleton test, $p<0.01$ ). This resulted in a high production of ammonium by both Shewanella and Duganella in the plankton extract addition (Supplementary Figure 3). The 

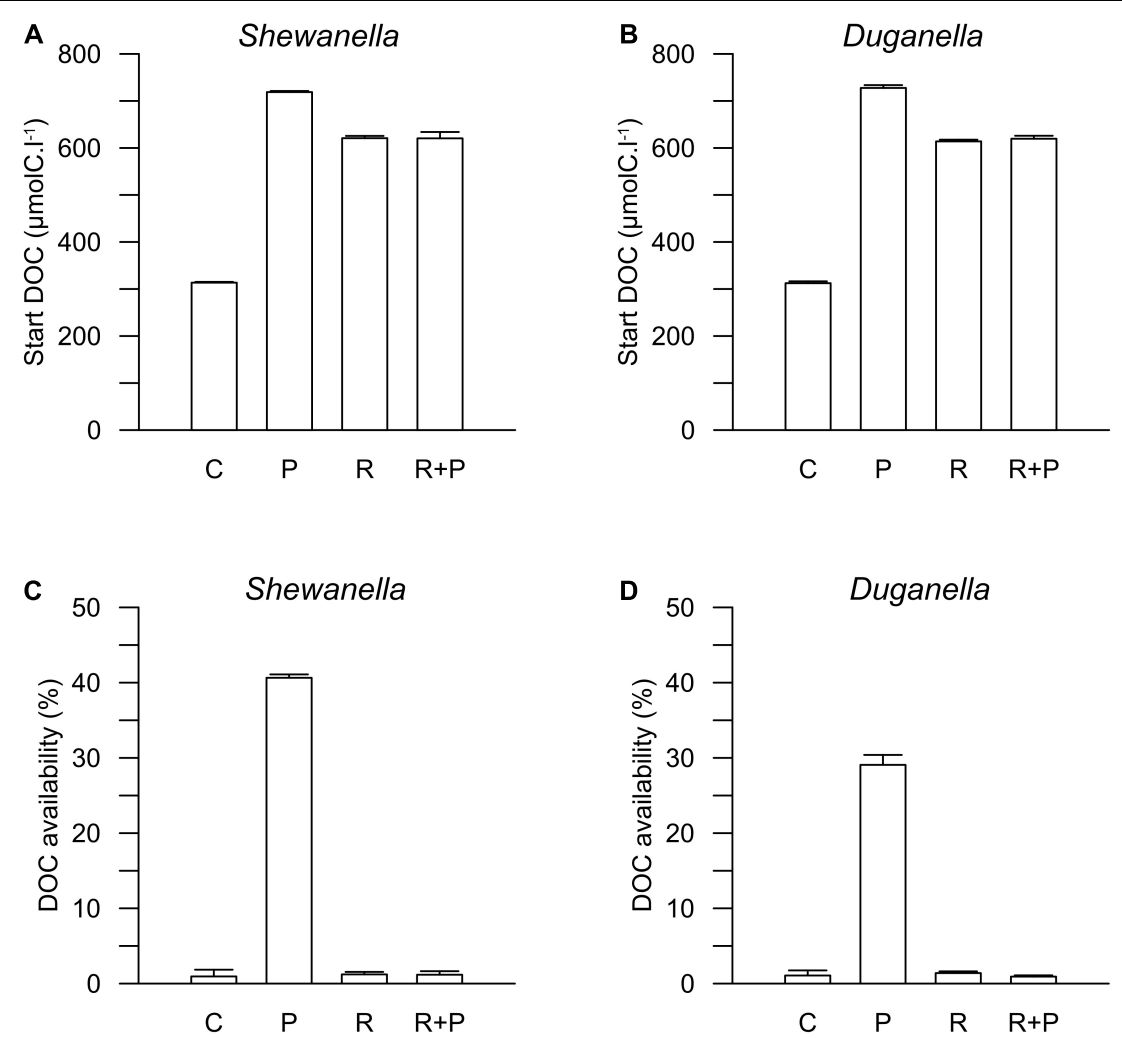

FIGURE 3 | Start concentration of DOC in (A) Shewanella and (B) Duganella incubations, and DOC availability in (C) Shewanella and (D) Duganella incubations. $\mathrm{C}=$ control; $\mathrm{P}=$ plankton extract; $\mathrm{R}$ = river extract; $\mathrm{R}+\mathrm{P}=$ river extract supplemented with phosphorus. Bar graphs show average values, and error bars denote standard deviation.

nitrate did not show large variations during the experiment in any of the treatments (Supplementary Figure 4), while the nitrite showed an increase in the plankton extract addition, which was slightly higher for Duganella (Supplementary Figure 5).

Shewanella was consuming TDP in all incubations, while for Duganella, a TDP consumption was observed only for the plankton extract amended microcosms (Supplementary Figure 6). In the plankton extract addition, the TDP consumption was higher for Shewanella than for Duganella (Epps-Singleton test, $p<0.01$ ). In parallel, phosphate was taken up by Shewanella while it was produced by Duganella in the plankton extract addition (Supplementary Figure 7).

TABLE $1 \mid \mathrm{C}, \mathrm{N}$, and $\mathrm{P}$ stoichiometry (moles) of the plankton and river extracts, and start values in the Control, River, River + P, and Plankton incubations in the microcosm experiment.

\begin{tabular}{lccc}
\hline Incubation & C:P & C:N & N:P \\
\hline Plankton extract & 71 & 1,216 & 0.1 \\
River extract & 58,947 & 825 & 71 \\
Control & 790 & 18 & 45 \\
River & 1,675 & 27 & 61 \\
River + P & 96 & 29 & 3 \\
Plankton & 78 & 5 & 16
\end{tabular}

\section{Bacterial Abundance and Carbon Biomass and Cell Yield}

At the start of the experiment, both bacteria were relatively large and had a high cell carbon content (Supplementary Table 4). However, over the time course of the experiment, when the cell abundances increased and the available carbon substrate was consumed, the bacteria decreased in size and lowered the cell carbon content. Such cell size decreases were observed for both bacteria and in all treatments.

The differences in DOC utilization mirrored the cell yield of bacteria (Figures 4C-F). The plankton extract triggered higher cell abundance and carbon biomass than the river extract and the control (Mann-Whitney test, $p<0.01$; Figures 1, 4C,D and Supplementary Figure 8), especially for the Shewanella bacterium. At the start of the experiment, the bacterial abundance was $\sim 0.2 \times 10^{6}$ cells. $\mathrm{ml}^{-1}$. In the control, the river extract addition, and the river extract $+\mathrm{P}$ addition, the end concentrations were $\sim 0.8 \times 10^{6}$ cells.ml $^{-1}$. However, in plankton extract supplemented microcosms, Duganella reached $1.5 \times 10^{6}$ cells. $\mathrm{ml}^{-1}$, and Shewanella reached as much as $18 \times 10^{6}$ cells. $\mathrm{ml}^{-1}$. The bacterial cell yield was relatively similar in the control, the river extract addition, and the river extract $+\mathrm{P}$ addition (Kruskal-Wallis, $p<0.01$; Mann-Whitney, $p>0.1$; Figures 4C,D). Nevertheless, the bacteria showed some differences when the river extract was the provided food 

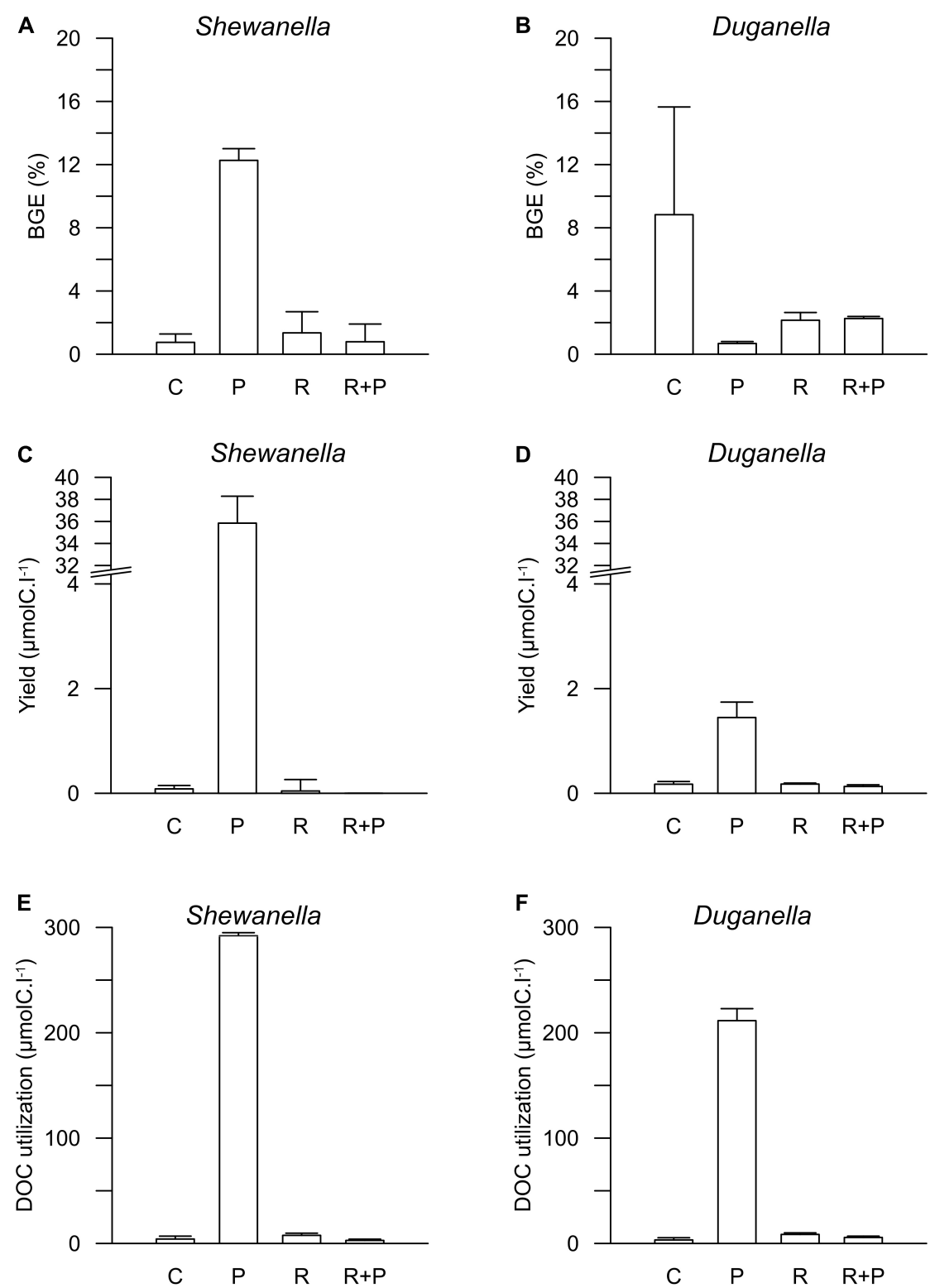

FIGURE 4 | Bacterial growth efficiency (BGE) in (A) Shewanella and (B) Duganella incubations, bacterial biomass yield in (C) Shewanella and (D) Duganella incubations, and DOC utilization in (E) Shewanella and $\mathbf{( F )}$ Duganella incubations. $\mathrm{C}=$ control; $\mathrm{P}=$ plankton extract; $\mathrm{R}=$ river extract; $\mathrm{R}+\mathrm{P}=$ river extract supplemented with phosphorus. Bar graphs show average values, and error bars denote standard deviation.

source. The cell yields of Duganella were $5.8 \times 10^{5}$ and $5.6 \times 10^{5} \mathrm{cell}^{\mathrm{ml}} \mathrm{m}^{-1}$ in the river extract and the river extract $+\mathrm{P}$, respectively, while the cell yields for Shewanella were $4.9 \times 10^{5}$ and $4.8 \times 10^{5} \mathrm{cell}^{\mathrm{m} \mathrm{m}^{-1}}$ in the river extract and the river extract $+\mathrm{P}$, respectively (Table 2 ). Taken together, the cell yield was significantly higher for Duganella in the river extracts compared to Shewanella (Epps-Singleton test, $p<0.01$ ).

\section{Variation in Bacterial Growth Efficiency}

The BGE values varied from $<1$ to $\sim 12 \%$ in the different treatments (Figures $\mathbf{4 A , B}$ and Table 2). For Shewanella, the highest BGE (12\%) was observed in the plankton extract addition
(Figure 4A and Table 2), while the corresponding BGE for Duganella was only $0.7 \%$. These BGE values were statistically different (Epps-Singleton test, $p<0.01$; Table 2). Duganella showed slightly higher BGE values (1-8\%) than Shewanella in the control, river, and river $+\mathrm{P}$ incubations, but these differences could not be statistically verified and therefore they should only be considered as indications. The addition of $\mathrm{P}$ to the river extract incubation did not lead to increased BGE of either of the two tested bacteria (Figures 4A,B and Table 2).

Furthermore, the results showed no indication that increased addition of carbon substrate, in general, caused elevated BGE. For 
TABLE 2 | Comparison of the DOC utilization, cell yield, carbon biomass yield, and growth efficiency (BGE) of the Duganella and the Shewanella bacterium in the Control, River extract, River extract $+\mathrm{P}$ and Plankton extract incubations in the microcosm experiment.

\begin{tabular}{|c|c|c|c|}
\hline Treatment & Measure & Duganella & Shewanella \\
\hline \multirow[t]{4}{*}{ Control } & $\begin{array}{l}\text { DOC utilization } \\
\left(\mu \mathrm{molC} . \mathrm{I}^{-1}\right)\end{array}$ & $3.6( \pm 2.1)$ & $4.2( \pm 2.7)$ \\
\hline & $\begin{array}{l}\text { Cell yield } \\
\left(\text { cell. } \mathrm{ml}^{-1}\right)\end{array}$ & $\begin{array}{c}5.7 \times 10^{5} \\
\left( \pm 4 \times 10^{3}\right)\end{array}$ & $\begin{array}{c}4.9 \times 10^{5} \\
\left( \pm 20 \times 10^{3}\right)\end{array}$ \\
\hline & $\begin{array}{l}\text { Biomass yield } \\
\left(\mu \mathrm{molC} . \mathrm{I}^{-1}\right)\end{array}$ & $0.17( \pm 0.05)$ & $0.08( \pm 0.07)$ \\
\hline & BGE (\%) & $8.8( \pm 6.8)$ & $0.7( \pm 0.5)$ \\
\hline \multirow[t]{4}{*}{ River extract } & $\begin{array}{l}\text { DOC utilization } \\
\left(\mu \mathrm{molC} . \mathrm{I}^{-1}\right)\end{array}$ & $8.5( \pm 1.5)$ & $7.6( \pm 2.1)$ \\
\hline & $\begin{array}{l}\text { Cell yield } \\
\left(\text { cell. } \mathrm{ml}^{-1}\right)\end{array}$ & $\begin{array}{c}5.8 \times 10^{5} \\
\left( \pm 9 \times 10^{3}\right)\end{array}$ & $\begin{array}{c}4.9 \times 10^{5} \\
\left( \pm 48 \times 10^{3}\right)\end{array}$ \\
\hline & $\begin{array}{l}\text { Biomass yield } \\
\left(\mu \mathrm{molC} . I^{-1}\right)\end{array}$ & $0.18( \pm 0.02)$ & $0.05( \pm 0.22)$ \\
\hline & BGE (\%) & $2.2( \pm 0.5)$ & $1.4( \pm 1.4)$ \\
\hline \multirow[t]{4}{*}{ River extract $+\mathrm{P}$} & $\begin{array}{l}\text { DOC utilization } \\
\left(\mu \mathrm{molC} . \mathrm{I}^{-1}\right)\end{array}$ & $5.7( \pm 1.1)$ & $7.2( \pm 2.8)$ \\
\hline & $\begin{array}{l}\text { Cell yield } \\
(\text { cell.ml-1) }\end{array}$ & $\begin{array}{c}5.6 \times 10^{5} \\
\left( \pm 2 \times 10^{3}\right)\end{array}$ & $\begin{array}{c}4.8 \times 10^{5} \\
\left( \pm 38 \times 10^{3}\right)\end{array}$ \\
\hline & $\begin{array}{l}\text { Biomass yield } \\
\left(\mu \mathrm{molC} . \mathrm{I}^{-1}\right)\end{array}$ & $0.13( \pm 0.03)$ & $-0.11( \pm 0.15)$ \\
\hline & BGE (\%) & $2.3( \pm 0.1)$ & $0.8( \pm 1.1)$ \\
\hline \multirow[t]{4}{*}{ Plankton extract } & $\begin{array}{l}\text { DOC utilization } \\
\left(\mu \mathrm{molC} . \mathrm{I}^{-1}\right)\end{array}$ & $211.5( \pm 11.4)^{\star}$ & $292.1( \pm 2.9)^{*}$ \\
\hline & $\begin{array}{l}\text { Cell yield } \\
\left(\text { cell. } \mathrm{ml}^{-1}\right)\end{array}$ & $\begin{array}{c}11 \times 10^{5} \\
\left( \pm 76 \times 10^{3}\right)^{\star}\end{array}$ & $\begin{array}{c}155 \times 10^{5} \\
\left( \pm 743 \times 10^{3}\right)^{\star}\end{array}$ \\
\hline & $\begin{array}{l}\text { Biomass yield } \\
\left(\mu \mathrm{molC} . I^{-1}\right)\end{array}$ & $1.45( \pm 0.29)^{\star}$ & $35.8( \pm 2.4)^{\star}$ \\
\hline & BGE (\%) & $0.7( \pm 0.1)^{\star}$ & $12.3( \pm 0.7)^{\star}$ \\
\hline
\end{tabular}

Values are means \pm standard deviation.

*Denotes significant differences between taxa at $p<0.01$ (Epps-Singleton test).

Duganella, the highest BGE was observed in the control, where the DOC concentration was the lowest. Neither did Shewanella have consistently higher BGE in the river and river $+\mathrm{P}$ additions compared to the control.

\section{Bioinformatic Analysis of Carbon Metabolic Genes in the Closest Genome of Shewanella baltica sp. and Duganella sp.}

In silico analysis of the closest genome of Shewanella baltica and Duganella sp. indicated that both studied bacteria have genes for the utilization of organic nitrogen compounds, nitrate assimilation, nutrient acquisition, and phosphate regulation (Table 3 and Supplementary Table 2). A total of 4,714 genes were assigned to functional COG categories in the Duganella genome, whereas in Shewanella, 3,115 genes were assigned to COG categories. Genes of functional category of carbohydrate transport and metabolism, inorganic ion transport and metabolism, signal transduction, and transcription are the most abundant group in the Duganella genome when compared to the Shewanella genome. The COG functional category and the distribution of the gene number in each category are listed in Supplementary Figure 9, and the complete comparative abundance list of predicted Pfam families is provided in Supplementary Table 5. The genome of Shewanella baltica harbors a gene involved in sucrose phosphorylase that is possibly involved in the regulation of sucrose metabolism, whereas this gene was absent from the genome of Duganella sp. In the genome of Shewanella baltica, we found a gene for glycogen phosphorylase, which is involved in the phosphorylase activity and degradation of glycogen. In addition, the Shewanella baltica genome includes a two-component system response regulator (ArcA) involved in the response to changes in oxygen levels. The genome of Shewanella baltica was found to have chitinase C involved in the metabolism for the utilization of chitin, whereas we did not identify genes encoding for chitinase in Duganella sp. The Shewanella baltica genome possesses $\mathrm{Na}^{+}$-translocating $\mathrm{NADH}$ :quinone oxidoreductase $\left(\mathrm{Na}^{+}-\mathrm{NQR}\right)$ encoding genes, which might function as the osmoregulation for sodium ion transport, whereas these genes are absent in the genome of Duganella sp. The gene encoding xylan esterase, cellulase, and pectin lyase was found in the genome of Duganella sp. for the enzymatic hydrolysis of lignocellulosic materials. The Duganella sp. genome harbors a gene encoding for gallate dioxygenase that degrades gallate. Moreover, a key gene for the utilization of aromatic carbon sources, like protocatechuate dioxygenase, is present in the genome of Duganella sp. but not in Shewanella baltica, and potentially reflects the adaptation to the river habitat of Duganella sp. Both these enzymes are needed in lignin decomposition, which is essential to the terrestrial carbon cycle.

\section{DISCUSSION}

\section{Plankton Extract More Bioavailable Than River Extract}

The plankton extract was more bioavailable (30-40\%) than the river extract (1-2\%) for both bacteria. The varying bioavailability was not due to a major difference in the molecular size of the extracts, since both consisted of high molecular weight compounds. However, they originated from different environments and were composed of biopolymers and terrestrial organic compounds, respectively, with large differences in elemental stoichiometry.

Shewanella showed 1.5 times higher DOC consumption of the plankton extract than did Duganella, and the abundance and biomass carbon yield were $\sim 20$-fold higher for Shewanella. The DOC availability of the river extract was similarly low for both of the bacteria. We expected that a shortage of phosphorus could be a limiting factor for DOC degradation, but the addition of $\mathrm{P}$ to the river extract did not increase the DOC bioavailability. Thus, the riverine DOC was truly refractory, and the low bioavailability was not due to a stoichiometric mismatch.

Many attempts have been made to identify coastal bacterial communities that are adapted to the degradation of terrestrial organic matter (e.g., Asmala et al., 2013; Herlemann et al., 2014; Figueroa et al., 2016). Most studies show that coastal bacteria are 
TABLE 3 | Comparative list of selected protein coding genes involved in carbon, nitrogen, and phosphorous metabolism in the closest genomes of Shewanella and Duganella species.

\begin{tabular}{|c|c|c|c|c|}
\hline Protein coding genes & $\begin{array}{c}\text { Shewanella } \\
\text { baltica OS117 }\end{array}$ & $\begin{array}{l}\text { Duganella sp. } \\
\text { AF9R3 }\end{array}$ & Functional roles & References \\
\hline $\begin{array}{l}\text { Carbon-nitrogen hydrolase } \\
\text { family protein }\end{array}$ & + & + & Reduction of organic nitrogen compounds & Bork and Koonin, 1994 \\
\hline $\begin{array}{l}\text { Nitrate reductase/nitrate } \mathrm{ABC} \\
\text { transporter permease }\end{array}$ & + & + & Nitrate assimilation & Smith et al., 2007 \\
\hline $\begin{array}{l}\text { Two-component sensor } \\
\text { histidine kinase }\end{array}$ & + & + & Nutrient acquisition and phosphate regulation & $\begin{array}{l}\text { Santos-Beneit, 2015; } \\
\text { Held et al., } 2019\end{array}$ \\
\hline Sucrose phosphorylase & + & - & Sucrose phosphorylase activity & Müller and Wegmann, 1978 \\
\hline $\begin{array}{l}\text { Glycogen/starch/alpha-glucan } \\
\text { phosphorylase }\end{array}$ & + & - & $\begin{array}{l}\text { Glycogen phosphorylase activity, linear } \\
\text { malto-oligosaccharide phosphorylase activity, alpha-glucan } \\
\text { phosphorylase activity }\end{array}$ & Schinzel and Nidetzky, 1999 \\
\hline Chitinase C & + & - & Hydrolysis of chitin by the enzyme bound to chitin & Watanabe et al., 1994 \\
\hline $\begin{array}{l}\mathrm{Na}^{+} \text {-translocating } \\
\mathrm{NADH} \text {-quinone reductase }\end{array}$ & + & - & Sodium ion transport & Hayashi et al., 2001 \\
\hline $\begin{array}{l}\text { Two-component system } \\
\text { response regulator ArcA }\end{array}$ & + & - & Response to changes in oxygen levels & Gao et al., 2008 \\
\hline Gallate dioxygenase & - & + & Ring-cleavage dioxygenase (gallate degradation) & $\begin{array}{l}\text { Kasai et al., 2005; } \\
\text { Nogales et al., } 2011\end{array}$ \\
\hline Cytochrome P450 & - & + & Polycyclic aromatic hydrocarbon degradation & Brezna et al., 2006 \\
\hline $\begin{array}{l}\text { Protocatechuate } \\
\text { 3,4-dioxygenase }\end{array}$ & - & + & $\begin{array}{l}\text { Benzoate degradation via hydroxylation and } \\
\text { 2,4-dichlorobenzoate degradation }\end{array}$ & Orville et al., 1998 \\
\hline Cellulase & - & + & Involved in degradation of cellulose & López-Mondéjar et al., 2016 \\
\hline Xylan esterase & - & + & Hydrolysis of lignocellulosic materials & López-Mondéjar et al., 2016 \\
\hline Pectin lyase & - & + & Pectin degradation & $\begin{array}{l}\text { Hugouvieux-Cotte-Pattat et al., } \\
2014\end{array}$ \\
\hline
\end{tabular}

,+- represent encoding genes present or absent in the closely related genome.

only able to degrade a small fraction of the coastal DOC and the riverine DOC entering the coast (e.g., Zweifel et al., 1993; Herlemann et al., 2014; Figueroa et al., 2016). Herlemann et al. (2014) performed an experimental study on the utilization of terrestrial DOM by a coastal bacterial community. They found that the DOC utilization was relatively low (4-16\%), and that neither the DOM composition nor the bacterial community composition changed during the experiment. They concluded that terrestrial DOC cannot be efficiently utilized by coastal bacteria. Our results are in line with these findings, as only $~ 2 \%$ of the DOC in the river extract was bioavailable for degradation by the bacteria. The lack of identified difference in DOC utilization between Shewanella and Duganella might be explained by a small consumption in a large pool. The variations were likely below the detection limit of the used analytical method.

We conclude that the plankton extract was much more bioavailable (20-fold) than the river extract, and that Shewanella was the most efficient user of the plankton extract. In contrast, the river extract was used to the same low degree by both bacteria. The river extract had similarly low bioavailability as the aged coastal seawater (control).

\section{Shewanella Adapted to Autochthonous Carbon-Duganella to Terrestrial Carbon}

At large, the measured range (from $<0.7$ to $\sim 12 \%$ ) of the BGE of the bacteria is in agreement with earlier studies performed in natural aquatic systems, like coastal waters, freshwaters, and oceanic waters (e.g., del Giorgio and Cole, 1998; Lee et al., 2009). Shewanella showed the highest BGE when the plankton extract was provided as the food substrate, while the river extract did not cause any elevated BGE. The plankton extract was considered to be of good quality because of its relatively high bioavailability and balanced C:P stoichiometry (close to the Redfield ratio). We interpret the BGE result as quality being an important factor for the BGE of Shewanella, while quantity itself is not important, at least within the tested range of concentrations. Even though the plankton extract also showed higher bioavailability for Duganella than in the control and the river extract, the biomass yield was not as pronounced as for Shewanella and the BGE was at minimum. Duganella consumed a substantial amount of plankton DOC, which did not translate into biomass. The carbon consumed by Duganella was likely respired, as efficient metabolic pathways were lacking as compared to the Shewanella bacterium. Unfavorable salinity could also cause increased respiration. We conclude that for this bacterium, neither good substrate quality nor high substrate concentration induced a high BGE. Instead, the highest BGE was observed in the control, which had relatively low DOC concentration of low quality (aged seawater).

In Shewanella, the presence of chitinase gene may function in the decomposition of chitin, which is the exoskeleton of some planktonic crustaceans (Souza et al., 2011). Furthermore, Shewanella has genes coding for phosphorylase enzymes that 
catalyze the addition of phosphates to carbon sources such as sucrose and glycogen (Table 3 ). The TDP consumption was twice as high for Shewanella than for Duganella. In the Shewanella microcosms, phosphate was consumed, while it was produced where Duganella was the inoculated bacterium. Furthermore, the Shewanella and Duganella genomes contain nitrate and nitrite reductase genes. However, genes for efficient reduction to ammonia were only found in Shewanella's genome (nap $B$, nap $C$, nap $D$, nap $E$, nrfA), which may render Shewanella more efficient at ammonium production when grown on the plankton extract (Supplementary Figure 3). Altogether, this shows that Shewanella is better adapted in utilizing the phosphorus-rich plankton extract containing easily available carbon sources than Duganella. Opportunistic bacteria, such as the studied Shewanella, would thus be functionally and genetically adapted to a life in eutrophied aquatic environments, where dead planktons are being degraded. In fact, the genus Shewanella has been shown to occur abundantly in such waters (Deng et al., 2019).

Even though the measured DOC consumption was low for both bacteria when the river extract was the provided food source, we found indications of differences in the performance of the bacteria, measured as BGE, cell yield, and carbon biomass yield. When the river extract was provided as the food substrate, Duganella showed slightly higher average BGE (1.6 times) and carbon biomass yield (4 times) than Shewanella, although with a large variation within treatment. The abundance yield of Duganella was significantly higher than of Shewanella when pooling the river extract and the river extract $+\mathrm{P}$ treatments. In the search of information in a closely related genome, we found that Duganella has the capability to produce several enzymes for the degradation of refractory material, such as lignocellulose and gallate, which Shewanella does not have (Table 3). Furthermore, genes encoding for cellulase, pectin lyase, and xylan esterase, present in Duganella but absent in Shewanella, may be involved in the hydrolysis of lignocellulosic material originating from terrestrial plants in the riverine extract. Altogether, the presence of genes in Duganella for aromatic compound degradation seems to have contributed to the adaptation of this bacterium in the riverine extract. In line with this, a recent study reported higher relative abundances of Duganella in forest riverine systems than in degraded rivers (Lin et al., 2019). In a famine environment, as in nutrient poor boreal rivers, carrying such genetic properties may mean survival and a competitive advantage in the environment.

We conclude that the utilization of the plankton extract as food source resulted in a relatively high carbon biomass production and BGE for Shewanella but not for Duganella. The reason for this difference is probably that Shewanella possesses genes for enzymes degrading autochthonously produced organic matter, while these are missing in Duganella. Another possibility is that the growth of Duganella was somewhat hampered due to the brackish water incubation. However, when the river extract was the provided food source, Duganella showed signs of being the more efficient bacterium, which may be explained by the presence of genes for the degradation of terrestrial organic matter.

\section{Link to the Occurrence of Bacteria in Rivers and Coasts}

It may be questioned how relevant it is to perform experiments with isolated organisms, since only a tiny fraction of all bacteria in aquatic environments are cultivable (Steen et al., 2019). However, the isolated bacteria we used in this study were representatives of common groups of bacteria in rivers and coasts. A Betaproteobacterium (Duganella) was isolated in the river mouth, and a Gammaproteobacterium (Shewanella) was isolated from the seaside area. The isolation of the bacteria did not occur randomly. Plankton extract was used for isolating coastal bacteria, while river extract was used for isolating river bacteria. The genus Shewanella constituted $60 \%$ of the coastal isolates, while the genus Duganella constituted $80 \%$ of the river isolates (Supplementary Table 1). Whereas it was possible to obtain bacterial isolates from both the coast and the river on agar plates with the plankton extract, no or very few colonies from the coastal water were growing on agar plates with the river extract. The bacteria were thus isolated on substrates originating from their natural environments. This indicates that we isolated ecologically relevant species, and that the results of the experiments would mirror their functions in the ecosystems.

Betaprotebacteria have been shown to be relatively abundant in freshwater, while Gammaproteobacteria are more common in nutrient-rich, saline waters (Herlemann et al., 2011). The study by Herlemann et al. (2011) showed that the relative abundance of Gammaproteobacteria increases along the northsouth salinity and productivity gradient of the Baltic Sea. The salinity ranges between 2 and 7 psu in the gradient, while the primary production and the phosphorus concentrations show a 10 - to 20-fold increase from north to south in the Baltic Sea (e.g., Andersson et al., 2015). Since Gammaproteobacteria are known to thrive in nutrient-rich environments (Andersson et al., 2018a), this could be part of the explanation for their salinity distribution pattern. Even if salinity can be an explanatory factor itself, the results of the present study conform to the nutrient-scavenging ecotype, which is common in some Gammaproteobacteria (e.g., Andersson et al., 2018a).

Salinity is a strong governing factor for the bacterial community composition in freshwater lakes and oceans (Herlemann et al., 2011; Colatriano et al., 2018). Marine bacteria have evolved strategies to manage elevated salinity concentrations, including a $\mathrm{Na}^{+}$-dependent respiratory chain, to counteract the osmotic stress (Walsh et al., 2013). However, at both our sampling sites, the salinity was $<5 \mathrm{psu}$, indicating that other environmental factors could have been of importance. Previous studies have shown that Duganella as well as Shewanella occur in both freshwater and brackish water (Duganella: Rappé et al., 2000; Lin et al., 2019) (Shewanella: Deng et al., 2014; Mathisen et al., 2016; Castillo et al., 2018). Both bacteria were isolated from brackish water, at a salinity of 0.9 and $4.4 \mathrm{psu}$, respectively, and the experiment was performed at a salinity of 
3.5-4 psu. However, we found that Shewanella harbored a gene for $\mathrm{Na}^{+}$-dependent respiratory chain (NQR) while Duganella did not. Differential salinity adaptation could thus be one of the explanatory factors for the varying results of the two bacteria. The growth of Duganella might have been somewhat hampered in the incubation salinity, while it was not the case for Shewanella.

The DOC concentration at the sampling sites was approximately twice as high in the river mouth $\left(\sim 667 \mu\right.$ molC. $\left.1^{-1}\right)$ than in the coast $\left(\sim 333 \mu\right.$ molC. $\left.1^{-1}\right)$, and the composition was also likely different, with more terrestrial material in the river mouth and more organic compounds originating from the marine system at the coastal site (Deutsch et al., 2012). We found genetic differences between the bacteria for carbon utilization, where Duganella is more versatile in the carbon utilization and has specific enzymes for the acquisition of aromatic compounds, while Shewanella has enzymes for the acquisition of carbohydrates such as glycogen sucrose and chitin. Accordingly, we think that the observed experimental differences mirror the adaptation to the carbon substrate composition and availability in the habitats from which the bacteria were isolated. Thus, the isolated bacteria seem to be ecologically relevant organisms, showing different adaptation to riverine and autochthonous marine food sources.

\section{CONCLUSION AND OUTLOOK}

The main findings of this study were that Shewanella was more adapted to utilize the plankton extract as the food source than Duganella, while Duganella showed signs of being better in utilizing the river extract as the food source. Furthermore, we can, at least partly, link these variations to differences in their genomes. A closely related genome of the studied Shewanella isolate was shown to harbor genes for the sequestration of autochthonously produced carbon substrates, such as sucrose and chitin. In contrast, a closely related genome of the studied Duganella lacked these properties. Instead, the genomic comparison indicated that the studied Duganella bacterium contained genes for the degradation of relatively refractive lignocellulosic material and gallate. However, these properties only caused a slightly average growth advantage on the river extract, which could not be clearly verified in this short-term experiment. Furthermore, differential salinity adaptation might have influenced the results.

In a long-term perspective, however, it might be beneficial for bacteria in coastal areas to carry genes encoding the degradation of terrestrial organic compounds, such as lignocellulosic material. In line with this, Chloroflexi bacteria in the Canada Basin, Western Arctic Ocean, have been shown to be replete with aromatic compound degradation genes, potentially enabling the bacteria to degrade organic matter originating from the

\section{REFERENCES}

Alonso-Sáez, L., Vázquez-Domínguez, E., Cardelús, C., Pinhassi, J., Sala, M. M., Lekunberri, I., et al. (2008). Factors controlling the year-round variability terrestrial system (Colatriano et al., 2018). Lateral gene transfer from terrestrial to marine bacteria was suggested to be one of the causative factors. The ability of bacteria to grow, even though slowly, on such compounds would mean a selective advantage compared to non-adapted bacterial taxa. Modeling studies indicate that, on a yearly basis, significant degradation of terrestrial organic carbon does occur in the Baltic Sea (Wikner and Andersson, 2012; Fransner et al., 2019). Moreover, according to global change models, the precipitation will increase in subarctic areas during the next 100 years (Andersson et al., 2015), and thus the inflow of terrestrial organic matter will increase in the coastal areas. A future perspective would thus be that the composition of the heterotrophic bacterial community in subarctic coastal areas will be driven toward taxa having a metabolic machinery for the degradation of complex terrestrial organic compounds.

\section{DATA AVAILABILITY STATEMENT}

The datasets presented in this study can be found in online repositories. The names of the repository/repositories and accession number(s) can be found in the article/Supplementary Material.

\section{AUTHOR CONTRIBUTIONS}

LZ, SB, and AA designed, performed, and analyzed the experiment. LZ and KR performed the molecular analyses. LZ, $\mathrm{SB}, \mathrm{KR}$, and AA wrote the manuscript. All authors contributed to the article and approved the submitted version.

\section{FUNDING}

This study was financed by the Swedish marine strategic research environment EcoChange (the Swedish Research Council Formas) to AA and Umeå Marine Sciences Centre to LZ.

\section{ACKNOWLEDGMENTS}

Umeå Marine Sciences Centre is gratefully acknowledged for laboratory assistance and chemical analyses.

\section{SUPPLEMENTARY MATERIAL}

The Supplementary Material for this article can be found online at: https://www.frontiersin.org/articles/10.3389/fmicb. 2021.726844/full\#supplementary-material

in carbon flux through bacteria in a coastal marine system. Ecosystems 11, 397-409. doi: 10.1007/s10021-008-9129-0

Andersson, A., Brugel, S., Paczkowska, J., Rowe, O. F., Figueroa, D., Kratzer, S., et al. (2018b). Influence of allochthonous dissolved organic matter on pelagic 
basal production in a northerly estuary. Estuar. Coast. Shelf Sci. 204, 225-235. doi: 10.1016/j.ecss.2018.02.032

Andersson, A., Ahlinder, J., Mathisen, P., Hägglund, M., Bäckman, S., Nilsson, E., et al. (2018a). Predators and nutrient availability favor protozoa-resisting bacteria in aquatic systems. Sci. Rep. 8:8415. doi: 10.1038/s41598-018-26422-4

Andersson, A., Meier, H. E., Ripszam, M., Rowe, O., Wikner, J., Haglund, P., et al. (2015). Projected future climate change and Baltic Sea ecosystem management. Ambio 44, 345-356. doi: 10.1007/s13280-015-0654-8

Asmala, E., Autio, R., Kaartokallio, H., Pitkänen, L., Stedmon, C. A., and Thomas, D. N. (2013). Bioavailability of riverine dissolved organic matter in three Baltic Sea estuaries and the effect of catchment land use. Biogeosciences 10, 6969-6986. doi: 10.5194/bg-10-6969-2013

Baña, Z., Abad, N., Uranga, A., Azúa, I., Artolozaga, I., Unanue, M., et al. (2020). Recurrent seasonal changes in bacterial growth efficiency, metabolism and community composition in coastal waters. Environ. Microbiol. 22, 369-380. doi: $10.1111 / 1462-2920.14853$

Benner, R., and Amon, R. M. W. (2015). The size-reactivity continuum of major bioelements in the ocean. Annu. Rev. Mar. Sci. 7, 185-205. doi: 10.1146/ annurev-marine-010213-135126

Bianchi, T. S. (2011). The role of terrestrially derived organic carbon in the coastal ocean: a changing paradigm and the priming effect. Proc. Natl. Acad. Sci. U.S.A. 108, 19473-19481. doi: 10.1073/pnas.1017982108

Bork, P., and Koonin, E. V. (1994). A new family of carbon-nitrogen hydrolases. Protein Sci. 3, 1344-1346. doi: 10.1002/pro.5560030821

Brezna, B., Kweon, O., Stingley, R. L., Freeman, J. P., Khan, A. A., Polek, B., et al. (2006). Molecular characterization of cytochrome P450 genes in the polycyclic aromatic hydrocarbon degrading Mycobacterium vanbaalenii PYR-1. Appl. Microbiol. Biotechnol. 71, 522-532. doi: 10.1007/s00253-005-0190-8

Broman, E., Asmala, E., Carstensen, J., Pinhassi, J., and Dopson, M. (2019). Distinct coastal microbiome populations associated with autochthonous and allochthonous-like dissolved organic matter. Front. Microbiol. 10:2579. doi: 10.3389/fmicb.2019.02579

Catalán, N., Obrador, B., Felip, M., and Pretus, J. L. (2013). Higher reactivity of allochthonous vs. autochthonous DOC sources in a shallow lake. Aquat. Sci. 75, 581-593. doi: 10.1007/s00027-013-0302-y

Castillo, D., Gram, L., and Dailey, F. E. (2018). Genome sequences of Shewanella baltica and Shewanella morhuae strains isolated from the gastrointestinal tract of freshwater fish. Genome Announc. 6:e00541-18. doi: 10.1128/genomeA. 00541-18

Chen, I. A., Chu, K., Palaniappan, K., Ratner, A., Huang, J., Huntemann, M., et al. (2021). The IMG/M data management and analysis system v.6.0: new tools and advanced capabilities. Nucleic Acids Res. 49, D751-D763. doi: 10.1093/nar/ gkaa939

Colatriano, D., Tran, P. Q., Guéguen, C., Williams, W. J., Lovejoy, C., and Walsh, D. A. (2018). Genomic evidence for the degradation of terrestrial organic matter by pelagic Arctic Ocean Chloroflexi bacteria. Commun. Biol. 1:90. doi: 10.1038/ s42003-018-0086-7

del Giorgio, P. A., and Cole, J. J. (1998). Bacterial growth efficiency in natural aquatic systems. Annu. Rev. Ecol. Syst. 29, 503-541. doi: 10.1146/annurev. ecolsys.29.1.503

Deng, J., Auchtung, J. M., Konstantinidis, K. T., Brettar, I., Höfle, M. G., and Tiedje, J. M. (2019). Genomic variations underlying speciation and niche specialization of Shewanella baltica. mSystems 4:e0560-19. doi: 10.1128/mSystems.00560-19

Deng, J., Brettar, I., Luo, C., Auchtung, J., Konstantinidis, K. T., Rodrigues, J. L., et al. (2014). Stability, genotypic and phenotypic diversity of Shewanella baltica in the redox transition zone of the Baltic Sea. Environ. Microbiol. 16, 1854-1866. doi: 10.1111/1462-2920.12344

Deutsch, B., Alling, V., Humborg, C., Korth, F., and Mörth, C. (2012). Tracing inputs of terrestrial high molecular weight dissolved organic matter within the Baltic Sea ecosystem. Biogeosciences 9, 4465-4475. doi: 10.5194/bg-9-44652012

Eiler, A., Langenheder, S., Bertilsson, S., and Tranvik, L. J. (2003). Heterotrophic bacterial growth efficiency and community structure at different natural organic carbon concentrations. Appl. Environ. Microbiol. 69, 3701-3709. doi: 10.1128/ AEM.69.7.3701-3709.2003

Epps, T. W., and Singleton, K. J. (1986). An omnibus test for the two-sample problem using the empirical characteristic function. J. Statistic. Comput. Simulat. 26, 177-203. doi: 10.1111/j.1541-0420.2012.01750.x
Eriksson-Hägg, H., Lyon, S. W., Wällstedt, T., Mörth, C. M., Claremar, B., and Humborg, C. (2014). Future nutrient load scenarios for the Baltic Sea due to climate and lifestyle changes. Ambio 43, 337-351. doi: 10.1007/s13280-0130416-4

Figueroa, D., Rowe, O. F., Paczkowska, J., Legrand, C., and Andersson, A. (2016). Allochthonous carbon-a major driver of bacterioplankton production in the subarctic northern Baltic Sea. Microb. Ecol. 71, 789-801. doi: 10.1007/s00248015-0714-4

Fouilland, E., and Mostajir, B. (2010). Revisited phytoplanktonic carbon dependency of heterotrophic bacteria in freshwaters, transitional, coastal and oceanic waters. FEMS Microbiol. Ecol. 73, 419-429. doi: 10.1111/j.1574-6941. 2010.00896.x

Fransner, F., Fransson, A., Humborg, C., Gustafsson, E., Tedesco, L., Hordoir, R., et al. (2019). Remineralization rate of terrestrial DOC as inferred from $\mathrm{CO}_{2}$ supersaturated coastal waters. Biogeosciences 16, 863-879. doi: 10.5194/bg-16863-2019

Gao, H., Wang, X., Yang, Z. K., Palzkill, T., and Zhou, J. (2008). Probing regulon of ArcA in Shewanella oneidensis MR-1 by integrated genomic analyses. BMC Genom. 9:42. doi: 10.1186/1471-2164-9-42

González-Benítez, N., García-Corral, L. S., Morán, X. A. G., Middelburg, J. J., Pizay, M. D., and Gattuso, J. P. (2019). Drivers of microbial carbon fluxes variability in two oligotrophic mediterranean coastal systems. Sci. Rep. 9:17669. doi: 10.1038/s41598-019-53650-z

Grasshoff, K., Ehrhardt, M., and Kremling, K. (1983). Methods of Seawater Analysis. Weinheim: Verlag Chemic.

Hagström, Å, Azam, F., Berg, C., and Zweifel, U. L. (2017). Isolates as models to study bacterial ecophysiology and biogeochemistry. Aquat. Microb. Ecol. 80, 15-27. doi: 10.3354/ame01838

Hammer, $\varnothing$, Harper, D. A. T., and Ryan, P. D. (2001). PAST: paleontological statistics software package for education and data analysis. Palaeontol. Electron. 4:9.

Hayashi, M., Nakayama, Y., and Unemoto, T. (2001). Recent progress in the Natranslocating NADH-quinone reductase from the marine Vibrio alginolyticus. Biochim. Biophys. Acta Bioenerget. 1505, 37-44. doi: 10.1016/s0005-2728(00) 00275-9

Held, N. A., McIlvin, M. R., Moran, D. M., Laub, M. T., and Saito, M. A. (2019). Unique patterns and biogeochemical relevance of two-component sensing in marine bacteria. mSystems 4:e0317-18. doi: 10.1128/mSystems. 00317-18

Herlemann, D. P., Labrenz, M., Jürgens, K., Bertilsson, S., Waniek, J. J., and Andersson, A. F. (2011). Transitions in bacterial communities along the 2000 ?km salinity gradient of the Baltic Sea. ISME J. 5, 1571-1579. doi: 10.1038/ ismej.2011.41

Herlemann, D. P. R., Manecki, M., Meeske, C., Pollehne, F., Labrenz, M., SchulzBull, D., et al. (2014). Uncoupling of bacterial and terrigenous dissolved organic matter dynamics in decomposition experiments. PLoS One 9:e93945. doi: 10. 1371/journal.pone.0093945

Hernroth, L. (1985). Recommendations on methods for marine biological studies in the Baltic Sea: mesozooplankton biomass assessment. Balt. Mar. Biol. 10, $1-32$.

Hugouvieux-Cotte-Pattat, N., Condemine, G., and Shevchik, V. E. (2014). Bacterial pectate lyases, structural and functional diversity. Environ. Microbiol. Rep 6, 427-440. doi: 10.1111/1758-2229.12166

Kasai, D., Masai, E., Miyauchi, K., Katayama, Y., and Fukuda, M. (2005). Characterization of the gallate dioxygenase gene: three distinct ring cleavage dioxygenases are involved in syringate degradation by Sphingomonas paucimobilis SYK-6. J. Bacteriol. 187, 5067-5074. doi: 10.1128/JB.187.15.50675074.2005

Lane, D. J. (1991). "16S/23S rRNA sequencing," in Nucleic Acid Techniques in Bacterial Systematics, eds E. Stackebrandt and M. Goodfellowedseds (Chichester: John Wiley and Sons), 115-175.

Lee, C. W., Bong, C. W., and Hii, Y. S. (2009). Temporal variation of bacterial respiration and growth efficiency in tropical coastal waters. Appl. Environ. Microbiol. 75, 7594-7601. doi: 10.1128/AEM. 01227-09

Lin, Q., Sekar, R., Marrs, R., and Zhang, Y. (2019). Effect of river ecological restoration on biofilm microbial community composition. Water 11:1244. doi: $10.3390 /$ w11061244 
Lønborg, C., Martínez-García, S., Teira, E., and Álvarez-Salgado, X. A. (2011). Bacterial carbon demand and growth efficiency in a coastal upwelling system. Aquat. Microb. Ecol. 63, 183-191. doi: 10.3354/ame01495

López-Mondéjar, R., Zühlke, D., Becher, D., Riedel, K., and Baldrian, P. (2016). Cellulose and hemicellulose decomposition by forest soil bacteria proceeds by the action of structurally variable enzymatic systems. Sci. Rep. 6:25279. doi: $10.1038 /$ srep25279

Marie, D., Simon, N., and Vaulot, D. (2005). "Phytoplankton cell counting by flow cytometry," in Algal Culturing Techniques, ed. R. A. Andersen (San Diego: Academic Press), 253-267. doi: 10.1016/B978-012088426-1/50018-4

Mathisen, P., Thelaus, J., Sjöstedt de Luna, S., and Andersson, A. (2016). Rapid adaptation of predation resistance in bacteria isolated from a seawater microcosm. Aquat. Microb. Ecol. 78, 81-92. doi: 10.3354/ame 01802

Menden-Deuer, S., and Lessard, E. J. (2000). Carbon to volume relationships for dinoflagellates, diatoms, and other protist plankton. Limnol. Oceanogr. 45, 569-579. doi: 10.4319/lo.2000.45.3.0569

Müller, W., and Wegmann, K. (1978). Sucrose biosynthesis in Dunaliella: I. Therm. Osmot. Regul. Planta 141, 155-158. doi: 10.1007/BF00387882

Nogales, J., Canales, A., Jiménez-Barbero, J., Serra, B., Pingarrón, J. M., García, J. L., et al. (2011). Unravelling the gallic acid degradation pathway in bacteria: the gal cluster from Pseudomonas putida. Mol. Microbiol. 79, 359-374. doi: $10.1111 / \mathrm{j} .1365-2958.2010 .07448 . \mathrm{x}$

Norland, S. (1993). "The relationship between biomass and volume of bacteria," in Handbook of Methods in Aquatic Microbial Ecology, eds P. H. Kemp, B. F. Sherr, E. B. Sherr, and J. J. Coleeds (London: Lewis publishers), 303-307. doi: 10.1201/9780203752746-36

Olenina, I., Hajdu, S., Edler, L., Andersson, A., Wasmund, N., Busch, S., et al. (2006). Biovolumes and size-classes of phytoplankton in the Baltic Sea. HELCOM Balt. Sea Environ. Proc. 106, 1-144.

Orville, A. M., Lipscomb, J. D., and Ohlendorf, D. H. (1998). Probing the reaction mechanism of protocatechuate 3,4-dioxygenase with X-ray crystallography. Keio J. Med. 45, 282-288. doi: 10.1007/978-4-431-68476-3_35

Pedler, B. E., Aluwihare, L. I., and Azam, F. (2014). Single bacterial strain capable of significant contribution to carbon cycling in the surface ocean. Proc. Natl. Acad. Sci. U.S.A. 111, 7202-7207. doi: 10.1073/pnas. 1401887111

Pérez-Pantoja, D., Donoso, R., Agulló, L., Córdova, M., Seeger, M., Pieper, D. H., et al. (2012). Genomic analysis of the potential for aromatic compounds biodegradation in Burkholderiales. Environ. Microbiol. 14, 1091-1117. doi: 10. $1111 / j .1462-2920.2011 .02613 . x$

Rappé, M. S., Vergin, K., and Giovannoni, S. J. (2000). Phylogenetic comparisons of a coastal bacterioplankton community with its counterparts in open ocean and freshwater systems. FEMS Microbiol. Ecol. 33, 219-232. doi: 10.1111/j.15746941.2000.tb00744.x

Santos-Beneit, F. (2015). The Pho regulon: a huge regulatory network in bacteria. Front. Microbiol. 6:402. doi: 10.3389/fmicb.2015.00402

Schinzel, R., and Nidetzky, B. (1999). Bacterial alpha-glucan phosphorylases. Appl. Environ. Microbiol. 171, 73-79. doi: 10.1016/s0378-1097(98)00580-1

Smith, C. J., Nedwell, D. B., Dong, L. F., and Osborn, A. M. (2007). Diversity and abundance of nitrate reductase genes (nar $G$ and napA), nitrite reductase genes (nirS and $n r f A$ ), and their transcripts in estuarine sediments. Appl. Environ. Microbiol. 73, 3612-3622. doi: 10.1128/AEM.02894-06

Søndergaard, M., and Middelboe, M. (1995). A cross-system analysis of labile dissolved organic carbon. Mar. Ecol. Prog. Ser. 118, 283-294. doi: 10.3354/ meps118283
Souza, C. P., Almeida, B. C., Colwell, R. R., and Rivera, I. N. (2011). The importance of chitin in the marine environment. Mar. Biotechnol. 13, 823-830. doi: 10.1007/ s10126-011-9388-1

Steen, A. D., Crits-Christoph, A., Carini, P., DeAngelis, K. M., Fierer, N., Lloyd, K. G., et al. (2019). High proportions of bacteria and archaea across most biomes remain uncultured. ISME J. 13, 3126-3130. doi: 10.1038/s41396-0190484-y

Teira, E., Nieto-Cid, M., and Álvarez-Salgado, X. A. (2009). Bacterial community composition and colored dissolved organic matter in a coastal upwelling ecosystem. Aquat. Microb. Ecol. 55, 131-142. doi: 10.3354/ame 01290

Utermöhl, H. (1958). Zur vervollkommnung der quantitativen phytoplanktonmethodik. Intern. Vereinigung Theoret. Angew. Limnol. Mitteilung. 9, 1-38. doi: 10.1080/05384680.1958.11904091

Vázquez-Domínguez, E., Vaqué, D., and Gasol, J. M. (2007). Ocean warming enhances respiration and carbon demand of coastal microbial plankton. Glob. Change Biol. 13, 1327-1334.

Vikström, K., and Wikner, J. (2019). Importance of bacterial maintenance respiration in a subarctic estuary: a proof of concept from the field. Microb. Ecol. 77, 574-586. doi: 10.1007/s00248-018-1244-7

Walsh, D. A., Lafontaine, J., and Grossart, H. P. (2013). "On the eco-evolutionary relationships of fresh and salt water bacteria and the role of gene transfer in their adaptation," in Lateral Gene Transfer in Evolution, ed. U. Gophna (New York, NY: Springer), 55-77.

Watanabe, T., Ito, Y., Yamada, T., Hashimoto, M., Sekine, S., and Tanaka, H. (1994). The roles of the C-terminal domain and type III domains of chitinase A1 from Bacillus circulans WL-12 in chitin degradation. J. Bacteriol. 176, 4465-4472. doi: 10.1128/jb.176.15.4465-4472.1994

Wikner, J., and Andersson, A. (2012). Increased freshwater discharge shifts the trophic balance in the coastal zone of the northern Baltic Sea. Glob. Change Biol. 18, 2509-2519.

Yeh, T. C., Krennmayr, K., Liao, C. S., Ejarque, E., Schomakers, J., Huang, J. C., et al. (2020). Effects of terrigenous organic substrates and additional phosphorus on bacterioplankton metabolism and exoenzyme stoichiometry. Freshw. Biol. 65, 1973-1988. doi: 10.1111/fwb.13593

Zweifel, U., Norrman, B., and Hagström, ^̊ (1993). Consumption of dissolved organic carbon by marine bacteria and demand for inorganic nutrients. Mar. Ecol. Prog. Ser. 101, 23-32. doi: 10.3354/meps101023

Conflict of Interest: The authors declare that the research was conducted in the absence of any commercial or financial relationships that could be construed as a potential conflict of interest.

Publisher's Note: All claims expressed in this article are solely those of the authors and do not necessarily represent those of their affiliated organizations, or those of the publisher, the editors and the reviewers. Any product that may be evaluated in this article, or claim that may be made by its manufacturer, is not guaranteed or endorsed by the publisher.

Copyright (๑) 2022 Zhao, Brugel, Ramasamy and Andersson. This is an open-access article distributed under the terms of the Creative Commons Attribution License (CC BY). The use, distribution or reproduction in other forums is permitted, provided the original author(s) and the copyright owner(s) are credited and that the original publication in this journal is cited, in accordance with accepted academic practice. No use, distribution or reproduction is permitted which does not comply with these terms. 